\title{
Risk factors for visceral leishmaniasis in selected high endemic areas of Morang, Nepal: A case control study
} Mandal PK, 1 D Wagle $\mathrm{RR}^{2}$, Uranw $\mathrm{S}^{3}$, Thakur $\mathrm{AK}^{4}$

'Punam Kumari Mandal, Instructor, Department of Community Health Nursing, Tribhuvan University, Institute of Medicine, Biratnagar Nursing Campus, Biratnagar, Nepal; ${ }^{2}$ Rajendra Raj Wagle, Professor, Department of Community Medicine, Karnali Academy of Health Sciences; ${ }^{3}$ Surendra Uranw, Assistant Professor, Department of Tropical Medicine, B.P. Koirala Institute of Health Sciences, Dharan; ${ }^{4}$ Ajoy Kumar Thakur, Assistant Professor, Department of Community Medicine, Tribhuvan University, Institute of Medicine, Kathmandu, Nepal.

\begin{abstract}
Background: Visceral leishmaniasis is a major public health concern in Nepal. During the last few years, several Kala-azar outbreaks have been reported from Terai region including Morang district, Nepal.

Objectives: The aim of this study is to determine the risk factors associated with Kala-azar at individual and household levels in selected highly endemic areas of Morang district of eastern Nepal.

Methodology: A case control study was conducted in five endemic village development committees of Morang district with 62 cases already treated from B.P. Koirala Institute of Health Sciences and Koshi Zonal Hospital. Two hundred and forty eight controls were selected randomly from the same village at the ratio of 1:4. Data was collected between September and November 2013 using semi structured questionnaires. Bivariate and multivariate analysis were done and the final model was selected using the backward elimination strategy.

Results: This study showed that the majority of cases (29.0\%) were from the 13-25 years age group, males are more than females and indigenous caste (74.2\%) were affected more than other caste. Living in thatched house (OR 4.57, $95 \% \mathrm{Cl} 1.91-10.93)$, ownership of animal (OR 3.95, 95\% Cl 1.87-8.37), sleeping on the ground floor (OR 3.90, 95\% Cl 1.838.31), history of migration to India and proximity to other Kala-azar cases within 50 metres distance of household were significant risk factors for visceral leishmaniasis. The association with socioeconomic status remained significant and there was a clear dose - response effect.

Conclusion: Living in thatched house, ownership of animals, sleeping on the ground floor, history of migration to India, proximity to other Kala-azar cases within 50 metres distance and poverty are the main risk factors associated with visceral leishmaniasis transmission.
\end{abstract}

Key words: Morang; Risk factors; Visceral leishmaniasis.

Access this article online

Website: www.jkmc.com.np

DOI: https://doi.org/10.3126/jkmc.v9i4.36406

HOW TO CITE

Mandal PK, Wagle RR, Uranw S, Thakur AK. Risk factors for visceral leishmaniasis in selected high endemic areas of Morang, Nepal: A case control study. J Kathmandu Med Coll. 2020;9(4):188-196.

Address for correspondence

Punam Kumari Mandal

Instructor, Department of Community Health Nursing

Biratnagar Nursing Campus

Biratnagar, Nepal

E-mail: poomandal@gmail.com

Copyright $\odot 2020$ Journal of Kathmandu Medical College (JKMC) ISSN: 2019-1785 (Print), 2091-1793 (Online) Attribution-Non Commercial 4.0 International License.

\section{INTRODUCTION}

$T$ ala-azar (KA) or visceral leishmaniasis (VL) is known Las a disease of the poorest of the poor because it predominantly affects the poor segment of the rural population with limited access to healthcare services ${ }^{1}$. In the endemic areas, children and young adults are its principal victims ${ }^{2}$. Kala-azar is one of the major public health problems in Nepal with approximately eight million population at estimated risk of disease i.e. $25 \%$ of the country population ${ }^{3}$.

Kala-azar was first officially recorded in Nepal in 1980 from one district, Dhanusha ${ }^{4}$. So far, officially 12 districts in the central and eastern Terai (low lands) bordering the north Bihar state of India are endemic to KA. However, there is also an increasing number of sporadic cases reported from other KA non-endemic districts including 
from the hilly regions ${ }^{5}$. During the last few years, several KA outbreaks have been reported from Terai region ${ }^{4,6}$. Reporting of KA outbreaks gradually has been increasing, affecting many parts of the country including Morang district. Morang district has been known to be the Kalaazar endemic zone for a long. In the Fiscal Year 2070/2071 the highest number of cases reported was from Morang district. The annual incidence rate was $0.84^{5}$.

A study conducted in Nepal found that bed net usage, ownership of cow, buffalo and damp floors were significantly associated with risk for $\mathrm{VL}^{8}$. Likewise, another study showed strong association with socioeconomic status, the poorest being most at risk. Housing was a risk factor, most at risk were those living in thatched houses without windows, sleeping upstairs and sleeping on a bet net were strongly protective ${ }^{13}$. Another study reports a VL incidence 5 per 10000 per year on the basis of notification by health facilities, but little community based information exists. Leishmaniasis infection rate in high transmission areas in Nepal is associated with gender, age and socioeconomic status ${ }^{15}$. The increasing number of KA outbreaks and sporadic distribution in the new kala-azar endemic area threatens the KA elimination program in Nepal. It is very essential to study the shifting of KA from one area to another. Risk factors data are essential to design the appropriate public health response to an endemic. However, there is little information available regarding the risk factors of KA in the context of Morang district. Therefore, it is essential to determine the risk factors for KA.

\section{METHODOLOGY}

\section{Design}

Case-control study design was used to determine the risk factors associated with Kala-azar at individual and household level in selected high endemic areas of Morang District, eastern Nepal.

\section{Settings}

General setting: In Morang District, there is open crossborder movement of people from Morang to Bihar state of India and vice versa due to sharing of similar culture and customs. Morang is administratively divided into 68 Village Development Committee (VDC) and 9 VDC is the reportedly affected area of Kala-azar. In Fiscal Year 2070/71 a total of 367 cases were reported, of which 339 cases were native and 28 cases were foreign cases. The highest number of cases (84) was reported from Morang District. The incidence rate was $0.84 .{ }^{5}$ Specific settings: The study was conducted in 5 VDC. These were Majhare, Bhathigach, Sisbanijahada, Katahari and Rangeli. These were the VDCs from where kala-azar cases are reported relatively in higher number (according to list available from District Public Health Office Morang)

\section{Study Population and Sample Size}

Kala-azar cases (prevalent case) who were treated last 2 year (from November 2011 to November 2013) at Koshi zonal hospital and BP Koirala Institute of Health Sciences (BPKIHS) Dharan from the affected area were selected as a case according to list available from Medical records at the DPHO. Controls were selected randomly from the updated 2012/13 voting register of Morang district at the ratio of 1:4. Control were the healthy individuals selected from the same population who had not suffered from VL in the past and did not present with fever and/ or splenomegaly on the day of the survey. Controls were matched age for cases to allow for inclusion of children in the group of control in the same proportion as cases, randomly selected adult voters were replaced by child. In such cases instead of taking adult voters, the children were enrolled. If there were no children in the household sampled a child was selected from the house of the nearest neighbor. The sample size was calculated through Epi Info 7 with. Two sided Confidence level = 95\%, power $(1-\beta)=80 \%$, case control ratio $=1: 4$ Percentage of control exposed $=38$, odds ratio $=2.4372$, percent of cases with exposure $=59.9$ based on study Risk Factor Analyses for South Asian Visceral Leishmaniasis and Implications for Elimination ${ }^{7}$. The sample size was 310 i.e. Cases $=62$ and control $=248$.

Ethical Approval: Before conducting the study ethical approval was taken from the Institutional Review Board of Institute of Medicine, Reference No. 32(6-11-E) 2 /070/071. Written informed consent was taken from each respondent prior to data collection. In case of children, parents or guardians were interviewed. Approval was taken from Concerned DPHO for use of Medical Records for selection of cases and permission was taken from Election Commission of Morang district before using updated voting register of 2012/1013 of Morang District for selection of control.

Data collection: Method of data collection was interview using a semi structured questionnaire. Prior to preceding the data collection work, a sketch map of each sampled wards was prepared in consultation with the local key persons such as Female Community Health Volunteers (FCHVs), teachers, social workers etc. Firstly, medical records at the DPHO, Morang was explored to compile the list of all Kala-azar cases who were treated last 2 years (from November 2011 to November 2013) and 
cases who gave 'Morang district' as their residence at the time of admission than those people were traced at their homes. Cases were all the confirmed KA cases that were treated at Koshi Zonal Hospital, Biratnagar and BPKIHS Dharan hospital. Controls were selected randomly from the updated 2012/13 voting register of Morang district. The register was based on a census of all citizens carried out in 2012/2013 in preparation of the elections and included all recent settlers at that time.

Data regarding household and risk factors were collected using a pre-tested semi-structured questionnaire by the principal investigator after obtaining the informed consent. Cases were asked to report their status at the time of their illness, for controls the status at the time of interview was recorded. In case of children, parents or guardians were interviewed.The study was conducted between September and November 2013.

Data entry and analysis: The filled questionnaires were thoroughly checked and edited before data entry. Data was entered in Epi data software version 3.1 by investigators and analyzed SPSS Version 16. Descriptive analysis e.g. rate, confidence interval, medians with inter quartile ranges were calculated. The probability of the difference between cases and controls occurring by chance was tested by means of chi -square test. Risk factors were estimated by calculating the odds ratio (OR) as an approximation of the relative risk with 95\% confidence interval (Cls). Observed associations were assessed through multivariate logistic regression. All variables with a $\mathrm{p}$-value $\leq 0.10$ in bivariate analysis were included in the multivariate logistic regression model after testing collinearity (tolerance $>0.1$ or VIF $<10$ ). Backward elimination strategy was used to select the variables for the final model. The probability of removal was set at $p=0.05$. Socio-economic status was assessed for the household, based on the validated asset index of Nepal Demographic Health Survey (NDHS) The asset index was converted into assets scores, using principal component analysis and categorized in level.

\section{RESULTS}

Among 310 respondents, the majority of cases 18 (29.0\%) were from the 13-25 years age group, males are more than females and indigenous caste 46 (74.2\%) were affected more than other castes. The majority of respondents were Hindu in comparison to others which comprised 49 (79\%) in cases and 202(81.5\%) in control whereas other religions (Christian, Buddhist, Kirat) comprised $13(21 \%)$ in cases and 46 (18.5\%)in control respectively. Majority of respondents were indigenous caste (Santhal + Mushar) by ethnic group being 46 (74.2\%) cases and 170 (68.5\%) controls followed by others which include Brahmin, Chetri, Baishya, Janajati, Dalit etc. Similarly, 23 (31.1\%) cases and 150 (60.5\%) controls were literate, 22 $(35.5 \%)$ cases and 40 (16.1\%) controls were from very low socioeconomic status (Table 1).

Regarding education, the odds of contracting kala-azar in literate countries were $62 \%$ less than illiterate (OR $0.38 \mathrm{Cl} 0.21-0.68)$. Similarly, in daily wage earners the risk of kala-azar is 2.15 times higher than others (student, preschool, housewife, private employee) (95\% Cl 1.11 4.16) (Table 2).

Respondents living in thatched houses had 4.72 times higher risk of contracting the disease than residents of brick houses (95\% Cl 2.29-9.71). The risk of having kalaazar was 2.42 times higher among those respondents whose house was nearby water collection $(95 \% \mathrm{Cl} 1.36-$ 4.29). Majority of cases 45 (72.6\%) sleep on the ground in comparison with controls 95 (38.3\%). The respondents who were sleeping on the ground had 4.26 times higher risk of getting the disease than the respondents who slept on bed (95\% Cl 2.31-7.88). Similarly, respondents who gave a history of migration to India had 3.35 times higher risk of getting the disease than others $(95 \% \mathrm{Cl}$ 1.84-6.10). The odds of having VL is 2.23 times higher in respondents who had relatives in Kala-azar endemic areas in India (95\% Cl 1.25-3.96) (Table 3).

This study revealed that people living in thatched house, sleeping in ground floor, ownership of animal, history of migration to India (Bihar and Jharkhand) and proximity to other KA cases within $50 \mathrm{~m}$ distance of household had high risk for VL. Education remains protective (OR $0.39,95 \% \mathrm{Cl}$ 0.19-0.79). The odds of getting VL among the respondents with proximity to $V L$ cases within $50 \mathrm{~m}$ distance was 2.63 times (95\% Cl 1.25-5.53) (Table 4).

The association with socioeconomic status remained significant and there was clear dose - response effect. The odds for VL consistently decreased as the level of socioeconomic status increased (OR 4.26, 3.81) (Table 5). 
Table 1: Socio-demographic Characteristics of Cases and Controls $(\mathbf{n}=\mathbf{3 1 0})$

\begin{tabular}{|c|c|c|c|}
\hline Variables & Case $(n=62), \%$ & $\operatorname{Control}(n=248), \%$ & Total $(n=310), \%$ \\
\hline \multicolumn{4}{|l|}{ Age (years) } \\
\hline $0-12$ & $16(25.8)$ & $64(25.8)$ & $80(25.8)$ \\
\hline $13-25$ & $18(29.0)$ & $72(29.0)$ & $90(29.0)$ \\
\hline $26-38$ & $16(25.8)$ & $64(25.8)$ & $80(25.8)$ \\
\hline $39+$ & $12(19.4)$ & $48(19.4)$ & $60(19.4)$ \\
\hline Median (inter quartile range) & $22.50(12-35)$ & & \\
\hline \multicolumn{4}{|l|}{ Gender } \\
\hline Male & $35(56.5)$ & $106(42.7)$ & $141(45.5)$ \\
\hline Female & $27(43.5)$ & $142(57.3)$ & $169(54.5)$ \\
\hline \multicolumn{4}{|l|}{ Religion } \\
\hline Hindu & $49(79.0)$ & $202(81.5)$ & $251(81.0)$ \\
\hline Others* & $13(21.0)$ & $46(18.5)$ & $59(19.0)$ \\
\hline \multicolumn{4}{|l|}{ Ethnic group } \\
\hline Indigenouscaste ${ }^{* *}$ & $46(74.2)$ & $170(68.5)$ & $216(69.7)$ \\
\hline Others & $16(25.8)$ & $78(31.5)$ & $94(30.3)$ \\
\hline \multicolumn{4}{|l|}{ Education } \\
\hline Literate & $23(37.1)$ & $150(60.5)$ & $173(55.80)$ \\
\hline Illiterate & $39(62.9)$ & $98(39.5)$ & $137(44.1)$ \\
\hline Primary & $13(21.0)$ & $90(36.3)$ & $103(33.2)$ \\
\hline Secondary & $8(12.9)$ & $55(22.2)$ & $63(20.3)$ \\
\hline SLCand above & $2(3.2)$ & $5(2.0)$ & $7(2.3)$ \\
\hline \multicolumn{4}{|l|}{ Occupation } \\
\hline Preschool & $6(9.7)$ & $21(8.5)$ & $27(8.7)$ \\
\hline Student & $19(30.6)$ & 79 (31.9) & $98(31.6)$ \\
\hline Agriculture & $6(9.7)$ & $34(13.7)$ & 40 (12.9) \\
\hline Daily labour & $17(27.4)$ & 37 (14.9) & $54(17.4)$ \\
\hline Small scale business & $0(0.0)$ & $2(0.8)$ & $2(0.6)$ \\
\hline Housewife & $13(21.0)$ & $73(23.4)$ & $86(27.7)$ \\
\hline Private employee & $1(1.6)$ & $2(0.8)$ & $3(0.9)$ \\
\hline
\end{tabular}

*others include christian, buddhist and kirat; ** Indigenous caste include Santhal and Mushar

Table 2: Socio-demographic and Economic Characteristics Associated with VL

\begin{tabular}{|c|c|c|c|c|c|}
\hline Factors & $\begin{array}{c}\text { Cases }(n=62) \\
(\%)\end{array}$ & $\begin{array}{c}\text { Control }(n=248) \\
(\%)\end{array}$ & Unadjusted $O R^{\dagger}$ & $95 \% \mathrm{Cl}^{\ddagger}$ & $\boldsymbol{P}$-value \\
\hline \multicolumn{6}{|l|}{ Sex } \\
\hline Male & $35(56.5)$ & $106(42.7)$ & 1.73 & \multirow{2}{*}{$0.99-3.04$} & \multirow{2}{*}{0.05} \\
\hline Female & $27(43.5)$ & $142(57.3)$ & (Ref) & & \\
\hline \multicolumn{6}{|c|}{ Marital status } \\
\hline Married & $32(51.6)$ & $135(54.4)$ & 0.89 & \multirow{2}{*}{$0.51-1.55$} & \multirow{2}{*}{0.69} \\
\hline Unmarried & $30(48.4)$ & $113(45.6)$ & (Ref) & & \\
\hline \multicolumn{6}{|l|}{ Religion } \\
\hline Hindu & 49(79.0) & $202(81.5)$ & 0.86 & \multirow{2}{*}{$0.43-1.71$} & \multirow{2}{*}{0.66} \\
\hline Others & $13(21.0)$ & $46(18.5)$ & (Ref) & & \\
\hline \multicolumn{6}{|l|}{ Ethnicity } \\
\hline Indigenous & $46(74.2)$ & $170(68.6)$ & 1.32 & \multirow{2}{*}{$0.70-2.47$} & \multirow{2}{*}{0.38} \\
\hline Other cast & $16(25.8)$ & $78(31.5)$ & (Ref) & & \\
\hline \multicolumn{6}{|l|}{ Education } \\
\hline Literate & $23(37.1)$ & $150(60.5)$ & 0.38 & \multirow{2}{*}{$0.21-0.68$} & \multirow{2}{*}{$0.0001^{*}$} \\
\hline Illiterate & $39(62.9)$ & $98(39.5)$ & (Ref) & & \\
\hline
\end{tabular}




\begin{tabular}{|c|c|c|c|c|c|}
\hline \multicolumn{6}{|l|}{ Occupation } \\
\hline $\begin{array}{l}\text { Daily wage } \\
\text { earner }\end{array}$ & $17(27.4)$ & $37(14.9)$ & 2.15 & $1.11-4.16$ & $0.02^{*}$ \\
\hline others & $45(72.6)$ & $211(85.1)$ & (Ref) & & \\
\hline \multicolumn{6}{|c|}{ Socioeconomic Status } \\
\hline Level 1 & $40(64.5)$ & $63(25.4)$ & (Ref) & & \\
\hline Level 2 & $13(21.0)$ & $121(48.8)$. & 5.91 & $2.94-11.85$ & $<0.001$ \\
\hline Level 3 & $9(14.5)$ & $64(25.8)$ & 4.51 & $2.02-10.07$ & $<0.001$ \\
\hline
\end{tabular}

* $\mathrm{p}<0.05$, $+\mathrm{OR}$, odds ratio $\neq \mathrm{Cl}$, confidence interval

Table 3: Behavioral Factors Associated with VL

\begin{tabular}{|c|c|c|c|c|c|}
\hline Factors & $\begin{array}{c}\text { Cases } \\
(n=62)(\%)\end{array}$ & $\begin{array}{c}\text { Control } \\
(n=248)(\%)\end{array}$ & Unadjusted $\mathbf{O R}^{\dagger}$ & $95 \% \mathrm{Cl}^{\ddagger}$ & $P$-value \\
\hline Ownership of bed nets & & & & & \\
\hline $\begin{array}{l}\text { Yes } \\
\text { No }\end{array}$ & $\begin{array}{c}58(93.6) \\
4(6.4)\end{array}$ & $\begin{array}{c}234(94.4) \\
14(5.6)\end{array}$ & $\begin{array}{l}0.86 \\
(\operatorname{Ref})\end{array}$ & $0.27-2.73$ & 0.810 \\
\hline $\begin{array}{l}\text { Sleep under bed net last night } \\
\text { Yes } \\
\text { No }\end{array}$ & $\begin{array}{l}52(89.7) \\
10(10.3)\end{array}$ & $\begin{array}{l}223(95.3) \\
25(4.7)\end{array}$ & $\begin{array}{l}0.43 \\
\text { (Ref) }\end{array}$ & $0.15-1.21$ & 0.100 \\
\hline Use of medicated bed nets & & & & & \\
\hline 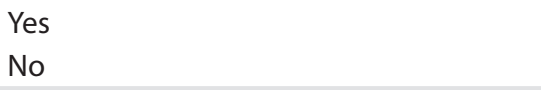 & $\begin{array}{l}21(36.8) \\
41(63.2)\end{array}$ & $\begin{array}{l}23(10.0) \\
225(90)\end{array}$ & $\begin{array}{l}5.22 \\
\text { (Ref) }\end{array}$ & $2.62-10.41$ & $0.000^{*}$ \\
\hline $\begin{array}{l}\text { Sleeping habit } \\
\text { Sleep on the ground } \\
\text { on bed }\end{array}$ & $\begin{array}{l}45(72.6) \\
17(27.4)\end{array}$ & $\begin{array}{c}95(38.3) \\
153(61.7)\end{array}$ & $\begin{array}{l}4.26 \\
\text { (Ref) }\end{array}$ & $2.31-7.88$ & $0.000^{*}$ \\
\hline $\begin{array}{l}\text { History of migration to India } \\
\text { Yes } \\
\text { No }\end{array}$ & $\begin{array}{l}26(41.9) \\
36(58.1)\end{array}$ & $\begin{array}{c}44(17.7) \\
204(82.3)\end{array}$ & $\begin{array}{l}3.35 \\
(\operatorname{Ref})\end{array}$ & $1.84-6.10$ & $0.000^{*}$ \\
\hline $\begin{array}{l}\text { Relatives in KA endemic areas in India } \\
\text { Yes } \\
\text { No }\end{array}$ & $\begin{array}{l}39(62.9) \\
23(37.1)\end{array}$ & $\begin{array}{l}107(43.2) \\
141(56.8)\end{array}$ & $\begin{array}{l}2.23 \\
\text { (Ref) }\end{array}$ & $1.25-3.96$ & $0.005^{*}$ \\
\hline $\begin{array}{l}\text { Alcohol use } \\
\text { Yes } \\
\text { No }\end{array}$ & $\begin{array}{l}25(40.3) \\
37(59.7)\end{array}$ & $\begin{array}{c}72(29.0) \\
176(71.0)\end{array}$ & $\begin{array}{l}1.65 \\
(\operatorname{Ref})\end{array}$ & $0.93-2.94$ & 0.080 \\
\hline
\end{tabular}

* $\mathrm{P}<0.05$, +OR odds ratio, $\neq \mathrm{Cl}$ confidence interval

Table 4: Household Factors Associated with VL

\begin{tabular}{|c|c|c|c|c|c|}
\hline Factors & $\begin{array}{c}\text { Cases } \\
(n=62)(\%)\end{array}$ & $\begin{array}{c}\text { Control } \\
(n=248)(\%)\end{array}$ & Unadjusted $\mathbf{O R}^{\dagger}$ & $95 \% \mathrm{Cl}^{\ddagger}$ & $P$-value \\
\hline \multicolumn{6}{|l|}{ Type of house } \\
\hline $\begin{array}{l}\text { Living in thatched house } \\
\text { Others }\end{array}$ & $\begin{array}{l}52(83.9) \\
10(16.1)\end{array}$ & $\begin{array}{l}130(52.4) \\
118(47.6)\end{array}$ & $\begin{array}{l}4.72 \\
\text { (Ref) }\end{array}$ & $2.29-9.71$ & $0.0001^{*}$ \\
\hline \multicolumn{6}{|l|}{ Presence of vegetation nearby house } \\
\hline $\begin{array}{l}\text { Yes } \\
\text { No }\end{array}$ & $\begin{array}{l}27(43.6) \\
35(56.4)\end{array}$ & $\begin{array}{l}129(52.0) \\
119(48.0)\end{array}$ & $\begin{array}{l}0.71 \\
(\text { Ref })\end{array}$ & $0.41-1.25$ & 0.231 \\
\hline $\begin{array}{l}\text { Presence of water collection nearby house } \\
\text { Yes } \\
\text { No }\end{array}$ & $\begin{array}{l}29(46.8) \\
33(53.2)\end{array}$ & $\begin{array}{l}66(26.6) \\
182(73.4)\end{array}$ & $\begin{array}{l}2.42 \\
(\operatorname{Ref})\end{array}$ & $1.36-4.29$ & $0.002^{*}$ \\
\hline \multicolumn{6}{|l|}{ Ownership of animals } \\
\hline $\begin{array}{l}\text { Yes } \\
\text { No }\end{array}$ & $\begin{array}{l}31(50.0) \\
31(50.0)\end{array}$ & $\begin{array}{c}51(20.6) \\
197(79.4)\end{array}$ & $\begin{array}{l}3.86 \\
(\operatorname{Ref})\end{array}$ & $2.15-6.93$ & $0.000^{*}$ \\
\hline
\end{tabular}




\begin{tabular}{|c|c|c|c|c|c|}
\hline \multicolumn{6}{|c|}{ Keeping animals INSIDE the house } \\
\hline Yes & $23(37.1)$ & $28(11.3)$ & 2.36 & \multirow{2}{*}{$1.57-5.35$} & \multirow{2}{*}{$0.000^{*}$} \\
\hline No & $8(62.9)$ & 23(88.7) & (Ref) & & \\
\hline \multicolumn{6}{|c|}{ Keeping animals in sleeping rooms } \\
\hline Yes & 11(17.7) & $13(5.2)$ & 1.60 & \multirow{2}{*}{$1.13-4.18$} & \multirow{2}{*}{$0.019 *$} \\
\hline No & $20(82.3)$ & $38(94.8)$ & (Ref) & & \\
\hline \multicolumn{6}{|c|}{ Presence of other diseases in house } \\
\hline Yes & $13(21.0)$ & $46(18.6)$ & 1.16 & \multirow{2}{*}{$0.58-2.32$} & \multirow{2}{*}{0.660} \\
\hline No & $49(79.0)$ & $202(81.4)$ & (Ref) & & \\
\hline \multicolumn{6}{|c|}{$\begin{array}{l}\text { Proximity of KA cases within } 50 \mathrm{~m} \text { of } \\
\text { distance }\end{array}$} \\
\hline Yes & $45(72.6)$ & $107(43.2)$ & 3.49 & \multirow{2}{*}{$1.89-6.43$} & \multirow{2}{*}{$0.000^{*}$} \\
\hline No & $17(27.4)$ & $141(56.8)$ & (Ref) & & \\
\hline \multicolumn{6}{|c|}{$\begin{array}{l}\text { Households sprayed with IRS within six } \\
\text { months }\end{array}$} \\
\hline Yes & $28(45.2)$ & $126(50.8)$ & 0.79 & \multirow{2}{*}{$0.45-1.39$} & \multirow{2}{*}{0.430} \\
\hline No & $34(54.8)$ & $122(49.2)$ & (Ref) & & \\
\hline
\end{tabular}

* $\mathrm{p}<0.05,+\mathrm{OR}$, odds ratio $\neq \mathrm{Cl}$, confidence interval

Table 5: Factors Associated with VL in a 'Multivariate' Analysis

\begin{tabular}{|c|c|c|c|c|}
\hline Factors & Unadjusted OR & Adjusted OR ${ }^{\dagger}$ & $95 \% \mathrm{Cl}^{\ddagger}$ & P-value \\
\hline \multicolumn{5}{|l|}{ Education } \\
\hline Literate & 0.38 & 0.39 & & \\
\hline Illiterate & (Ref) & (Ref) & $0.19-0.79$ & 0.010 \\
\hline \multicolumn{5}{|l|}{ Type of housing } \\
\hline Living in thatched house & 4.72 & 4.57 & & \\
\hline Others & (Ref) & (Ref) & $1.91-10.93$ & 0.0006 \\
\hline \multicolumn{5}{|l|}{ Ownership of animals } \\
\hline Yes & 3.86 & 3.95 & & \\
\hline No & (Ref) & (Ref) & $1.87-8.37$ & 0.0003 \\
\hline \multicolumn{5}{|l|}{ Sleeping habit } \\
\hline Sleep on ground floor & 4.26 & 3.90 & & \\
\hline on the bed & (Ref) & (Ref) & $1.83-8.31$ & 0.0004 \\
\hline \multicolumn{5}{|c|}{ History of migration to India (Bihar \& } \\
\hline \multicolumn{5}{|c|}{ Jharkhand) } \\
\hline Yes & 3.35 & 4.85 & & \\
\hline No & (Ref) & (Ref) & $2.22-10.59$ & 0.0001 \\
\hline \multicolumn{5}{|c|}{ Proximity to other KA cases within $50 \mathrm{~m}$ distance } \\
\hline Yes & 3.49 & 2.63 & & \\
\hline No & (Ref) & (Ref) & $1.25-5.53$ & 0.0105 \\
\hline \multicolumn{5}{|c|}{ Socio economic status by PCA } \\
\hline Level 1 & (Ref) & (Ref) & & \\
\hline Level 2 & 5.91 & 4.26 & $0.28-2.66$ & 0.0005 \\
\hline Level 3 & 4.51 & 3.81 & $1.42-10.16$ & 0.0075 \\
\hline
\end{tabular}

†OR, Adjusted odds ratio; $\neq \mathrm{Cl}$ confidence interval

\section{DISCUSSION}

In this study the age group 13-25 years comprises $29 \%$ in both cases and control while in other studies conducted in national level and regional level shows incidence is very high among age group $15-40$ years i.e. $60 \%{ }^{8}$. It indicates that this age group has the highest incidence of $\mathrm{VL}$ in comparison to other age groups. In this study the rate of infection was higher in indigenous castes (74.2\%) than other castes which suggest that indigenous castes have a higher chance of contracting the disease than others. 
A study conducted in India suggests that VL typically clusters in marginalized communities of the villages at hamlet level, such as the Mushar community in India9, ${ }^{10}$. Mushars (the lowest caste in Bihar) had twice the odds to be 'late presenters' compared to the rest of castes (OR 2.05, 95\% Cl 1.24-2.38) ${ }^{11}$. In the context of Nepal, more indigenous people (Santhal+ Mushar) reside in eastern region, ${ }^{12}$ this could be one of the reasons that kala-azar is more endemic in eastern region than western region. In this study the higher infection rate of VL was found in men than women and similar ratio has been observed in relation to VL cases in study conducted on Epidemiology of Leishmania donovani infection in high-transmission foci in Nepal. ${ }^{13}$.Although those differences are generally attributed to a more frequent exposure of males than females to sand flies, e.g. as men often spend days away from home for seasonal work in farms, there could also be an under detection of disease in women in traditionally male dominated societies. Another behavioral-related factor is that women in those communities wear long dresses which could prove to be protective to some degree from sand fly biting.

Literacy is a protective factor (OR $0.39,95 \% \mathrm{Cl} 0.18-0.78$ ). Our study showed that VL cases come from households with lower socioeconomic status than controls, compared with controls VL cases had thatched house, owned less land and were more likely to be daily laborer. Kala-azar is related to poverty, affecting 'the poorest of the poor'. In poor states such as Bihar in India and Nepal, VL affects families in the lowest income groups, who already live on less than US $\$ 1$ per day. The relationship between leishmaniasis and poverty is complex: while poverty increases the risk for VL and aggravates disease progression, VL itself leads to further impoverishment of the family due to catastrophic health expenditure, income loss and death of wage earners ${ }^{14}$.

Bed nets are already in wide use in this area, largely as protection against nuisance mosquitoes. More than $95 \%$ of the control group reported the regular use of bed nets. However, the use of medicated bed net is higher in cases in comparison to controls as PSI international distributed medicated bed net to all diagnosed cases of VL.

In multivariate analysis, the final model showed a very strong association between VL and certain housing factors, those living in a thatched house having 4.57 times higher odds of kala-azar. Sleeping on the ground floor is a strong risk factor for kala-azar (OR 3.90, 95\% Cl 1.838.31). A number of studies in the Indian subcontinent investigated risk factors for $\mathrm{VL}$, and most of them have been recently reviewed in detail, generally risk factors for
VL were mainly linked to precarious housing conditions 15. VL is a rural disease and associated with precarious housing conditions (mud plastered houses) and environment (humid soil and organic debris) of the poor communities. The proliferation of vectors is enhanced by poor housing conditions which provide excellent breeding sites for sand flies and increased the risk of infection through the bite of vectors or increased humanvector contact. In this study concerning the association of living in thatched house with VL are supported by other studies conducted in India that cracked house walls were associated with an increased risk of VL infection ${ }^{15,16,18}$. A recent study from India has shown evidence for mud plastered houses as a risk factor for $\mathrm{KA}^{16}$. As high soil humidity favors an ideal breeding habitat for sand flies, they may be more attracted to house near water collection ${ }^{17}$. In this study presence of water collection nearby house was significant in bivariate analysis with odds of 2.42 (95\% Cl 1.36-4.29). In rural areas, houses are usually surrounded by moderate-to-high density vegetation such as seasonal crops, bananas, bamboo trees, climbers and herbs. However, the presence of vegetation was not significantly associated with KA cases in bivariate analysis.

In this study proximity to previous kala-azar cases is also risk factors for $\mathrm{VL}$ (OR 2.63, 95\% Cl 1.25-5.53) as $72.6 \%$ of cases were living in proximity of kala-azar cases at $50 \mathrm{~m}$ distance compared to $43.2 \%$ control. This clustering pattern suggests that active VL cases are the main source of transmission and is an important risk factor for L. donovani infection. The recent initiatives on active case detection strategy have included an index case based approach in Nepal ${ }^{35}$. The index case based approach includes the search of new VL and Post Kala-azar Dermal Leishmaniasis (PKDL) cases among the household members through house to house visits around a house (radius of $50 \mathrm{~m}$ or 100 households) of a recently diagnosed VL case. It is important to increase the awareness of communities about the disease and its control.

Ownership of animal was strong risk factors as respondents who had animal in their house having 3.95 times higher risk of contracting the disease than others (95\% Cl 1.87-8.37). The subjects who kept animal inside their house having 2.36 times higher risk of getting the disease $(95 \% \mathrm{Cl} 1.57-5.35)$ in bivariate analysis but it was not significant in multivariate model. The role of domestic animals as a risk factor for VL is still controversial. The presence of cattle is associated with increased risk in some studies and decreased risk in others, reflecting the complexity of the effect of bovines 
on sand fly abundance, aggregation, feeding behavior and leishmanial infection rates $^{7}$. In contrast to Latin America and Europe, where the host reservoir of $\mathrm{VL}$ is the domestic dog, humans are assumed to be the only reservoir on the Indian Subcontinent. Yet, domestic animals can play a role in the transmission of VL on the Indian subcontinent because of their association with the sandfly vector. Animals may either attract sandflies, thereby increasing vector density and transmission to humans; or they may serve as an alternative blood meal source, thereby decreasing transmission ${ }^{18}$.

Similarly, history of migration to India (Bihar \& Jharkhand) was a strong risk factor for VL having 4.85 times higher odds of VL than others who did not travel $(95 \% \mathrm{Cl} 2.22$ 10.59). These findings reflect that these associations are all consistent with other studies as similar findings were found in a study conducted in Dharan ${ }^{6}$.

Kala-azar is predominantly a rural disease'. Recently kala-azar cases have been reported from Bhojpur and Okhaldhunga districts, in the hilly non-endemic region. Many of these were treated at BPKIHS hospital. Because of intense migration, VL cases in hilly regions could have been infected with L. donovani in the Terai, but there is a definite concern about the possibility of local

\section{REFERENCES}

1. Boelaert M, Meheus F, Sanchez A. et al. Poorest of the poor: a poverty appraisal of households affected by visceral leishmaniasis in Bihar, India. Tropical Medicine and International Health. 2009;14:639-44. [PubMed]

2. ChappuisF, Sundar S, Hailu A, Ghalib H, Rijal S, Peeling RW, Alvar J, Boelaert M. Visceral leishmaniasis: what are the needs for diagnosis, treatment and control? Nat Rev Microbiol. 2007 Nov;5(11):873-82. [PubMed]

3. Rijal S, Bhandari S, Koirala $\mathrm{S}$ et al. Clinical risk factors for therapeutic failure on Kala-azar patients treated with pentavalent antimonial in Nepal. Transaction of the Royal Society of Tropical Medicine and Hygiene. 2010;104:225-29.[DOI]

4. Bista MB. National overview of kala-azar in Nepal. In: Kala-azar in Nepal: Principals, Practices and Public Health Perspectives (edsBastola S, Karki P, Rijal S \&GautamA) EDCD/BPKIHS/WHO, Kathmandu, 1998 pp.1-5.

5. Ministry of Health \& Population/disease control, Annual Report (2070/2071) 2015,93-97 [Internet]. [Full Text] transmission for several reasons. This should be verified and investigated urgently, because if these cases are the result of local transmission in these hills, then the national control program needs to revise its control strategy urgently.

\section{CONCLUSION}

Living in thatched house, ownership of animals, sleep on ground floor, history of migration to India (Bihar and Jharkhand), proximity to other KA cases within $50 \mathrm{~m}$ distance and poverty are the main risk factors associated with $\mathrm{VL}$ transmission in the $\mathrm{VL}$ endemic villages of Morang district. Similarly, the ownership of animals is also strongly associated with VL transmission.

\section{ACKNOWLEDGEMENT}

Researchers would like to express sincere gratitude to Tribhuvan University, Institute of Medicine for Granting the opportunity to carry out this study. We would like to extend my cardinal thanks to the staff of DPHO Morang and all the respondents for their kind cooperation and valuable time.

\section{Conflict of interest: None Source(s) of support: None}

6. Uranw S, Hasker E, Roy L, Meheus F, Das ML, Bhattarai NR et al. An outbreak investigation of visceral leishmaniasis among residents of Dharan town eastern Nepal, evidence for urban transmission of Leishmania donovani. BMC Infectious Diseases. 2013;13:21.[DOI]

7. Bern C, Courtenay O, Alvar J. Of Cattle, Sand Flies and Men: A systematic review of risk factor analyses for south asian visceral leishmaniasis and implications for elimination. PLoSNegl Trop Dis. 2010;4(2):e599. [DOI]

8. Bern C, Joshi A.B, Jha SN, Das, ML et al, factors associated with visceral leishmaniasis in Nepal : Bed-Net use is strongly protective. Am j Trop. Med. Hyg.2000; 63:184-188. [DOI]

9. Ahluwalia IB, Bern C, Costa C, Akter T, Chowdhury R, Ali M, et al. Visceral leishmaniasis: consequences of a neglected disease in a Bangladeshi community. The American journal of tropical medicine and hygiene. 2003;69(6):624-8. [PubMed]

10. Hasker $E$, Singh $S$, Malaviya $P$, Singh $R$, Shankar $R$, Boelaert $M$, et al. Management of visceral leishmaniasis in rural primary health care services in Bihar, India. Tropical Medicine \& International Health. 2010;15(s2):55-62. [DOI] 
11. Pascual Martinez F, Picado A, Roddy P, Palma P. Low castes have poor access to visceral leishmaniasis treatment in Bihar, India. Tropical Medicine \& International Health. 2012;17(5):666-73. [DOI]

12. Nepal population and housing census 2011 ,National Report,volume 01,NPHC 2011. [Full Text]

13. Rijal S, Uranw S, Chappuis F, Picado A, Khanal B, Paudel IS, Andersen EW, Meheus F, Ostyn B, Das ML, Davies C. Epidemiology of Leishmania donovani infection in high transmission foci in Nepal. Tropical Medicine \& International Health. 2010 Jul;15:21-8. [DOI]

14. Alvar J, Yactayo S, Bern C. Leishmaniasis and poverty. Trends in parasitology. 2006;22(12):552-7. [DOI]

15. Singh SP, Reddy DCS, Rai M, Sundar S. Serious underreporting of visceral leishmaniasis through passive case reporting in Bihar, India. Tropical Medicine and International Health. 2006;11:899-905. [PubMed]

16. Ranjan A, Sur D, Singh VP, Siddique NA, Manna B, Lal CS, et al. Risk factors for Indian kala-azar. The American journal of tropical medicine and hygiene. 2005;73(1):74-8.[DOI]

17. Schenkel K, Rijal S, Koirala $S$ et al. Visceral leishmaniasis southeastern Nepal: A cross-sectional survey on Leishmania donovani infection and its risk factors. Tropical Medicine and International Health. 2006;11:1792-9. [DOI]

18. Singh SP, Hasker E, Picado A, Gidwani K, Malaviya P et al. Risk factors for visceral leishmaniasis in India: Further evidence on the role of domestic animals. Trop Med Int Health. 2010; 15(2):29-35. [DOI]

19. Bhattacharya SK, Dash AP. Elimination of Kala-Azar from the Southeast Asia region. Am J Trop Med Hyg. 2017 Apr;96(4):802-4.[ DOI]

20. Cerbino J, Guilherme N, Werneck L, Henrique C, Costa N. Factors associated with the incidence of urban visceral leishmaniasis: an ecological study in Teresi Cad. Saude Publica, Rio de Janeiro. 2009 Jul;25(7):1543-51. [DOI]

21. Saha S, Ramachandran R, Hutin YJ, Gupte MD. Visceral leishmaniasis is preventable in a highly endemic village in West Bengal, India. Transactions of the Royal Society of Tropical Medicine and Hygiene. 2009;103(7):737-42. [DOI]

22. Bashaye $S$, Nombela N, Argaw D et al. Risk factors for visceral leishmaniasis in a new epidemic site in Amhara region, Ethiopia. Am. J. Trop. Med. Hyg. 2009; 81(1):34-9. [PubMed]

23. Kolaczinski $\mathrm{JH}$, Reithinger R, Worku DT, Ocheng A, Kasimiro J, Kabatereine $\mathrm{N}$ et al. Risk factors of visceral leishmaniasis in East Africa: A case-control study in Pokot territory of Kenya and Uganda. Int J Epidemiol. 2008; 37:344-52. [PubMed]

24. Kajaia M, Morse DL, Kamkamidze1 G, Butsashvili M, Chubabria $\mathrm{G}$ et al. Risk factors for relapse of visceral leishmaniasis in Georgia. Tropical Medicine and International Health. 2011 Feb;16(2):186-92. [DOI]

25. Bern C, Hightower AW, Chowdhury R, Ali M, Amann J, Wagatsuma $Y$, et al. Risk factors for kalaazar in Bangladesh. Emerging infectious diseases. 2005;11(5):655. [Full Text]

26. Addy $M$, Nandy A. Ten years of kala-azar in west Bengal, Part I. Did post-kala-azar dermal leishmaniasis initiate the outbreak in 24-Parganas? Bulletin of the World Health Organization. 1992;70(3):341. [PubMed]

27. Alexander B, de Carvalho RL, McCallum $H$, Pereira $\mathrm{MH}$. Role of the domestic chicken (Gallus gallus) in the epidemiology of urban visceral leishmaniasis in Brazil. Emerging infectious diseases. 2002;8(12):1480. [PubMed]

28. Quinnell R, Dye C, Shaw J. Host preferences of the phlebotomines and fly Lutzomyia longipalpis in Amazonian Brazil. Medical and Veterinary Entomology. 1992;6(3):195-200. [DOI]

29. DiagnosisandManagement of VisceralLeishmaniasis (Kala Azar) in Kenya ,National Guidelines for Health Workers,revised in january 2012. [Full Text]

30. Koirala S, Parija S.C, Karki P, Das M.L. Knowledge, attitudes,and practices about kala-azar and its sandfly vector in rural communities of Nepal. Bulletin of the WHO,1998;76:485-90. [PubMed]

31. Mondal D, Singh SP, Kumar N, Joshi A, Sundar S, Das P, et al. Visceral leishmaniasis elimination programme in India, Bangladesh, and Nepal: reshaping the case finding/case management strategy. PLoS neglected tropical diseases. 2009;3(1):e355. [DOI]

32. Snider H, Lezama-Davila C, Alexander J, Satoskar AR. Sex hormones and modulation of immunity against leishmaniasis. Neuroimmunomodulation. 2009;16(2):106-13. [PubMed]

33. Meeting WECotCotL. Control of the leishmaniases: Report of a meeting of the WHO expert committee on the control of leishmaniases, Geneva, 22-26 March 2010: World Health Organization; 2010. [Full Text]

34. Zijlstra E, Musa A, Khalil E, El Hassan I, El-Hassan A. Post-kala-azar dermal leishmaniasis. The Lancet infectious diseases. 2003;3(2):87-98. [Full Text]

35. Government of Nepal, Ministry of Health and Population, national strategic guideline on kala-azar elimination program in Nepal. 2014;19.[Full Text] 